\title{
GAMBARAN HISTOLOGIK JARINGAN LIMPA TIKUS PUTIH (Rattus norvegicus) YANG DIINFEKSI ESCHERICIA COLI DAN DIBERI MADU
}

\author{
${ }^{1}$ Christiani Matheos \\ ${ }^{2}$ Poppy Lintong \\ ${ }^{2}$ Carla Kairupan
}

\author{
${ }^{1}$ Kandidat Skripsi Fakultas Kedokteran Universitas Sam Ratulangi Manado \\ ${ }^{2}$ Bagian Patologi Anatomi Kedokteran Universitas Sam Ratulangi Manado \\ Email: ithien_matheos@yahoo.com
}

\begin{abstract}
Abstrak: Daya antimikroba dalam madu dipengaruhi oleh kandungan glukosanya yang tinggi, tingkat keasaman madu, serta senyawa flavonoid yang dapat mengikat radikal bebas dan melawan agen infeksi. Eschericia coli dapat menimbulkan infeksi lokal organ tubuh, mencapai aliran darah, dan menimbulkan sepsis. Penelitian ini bertujuan untuk mengetahui perubahan gambaran histologik jaringan limpa tikus yang diinfeksi E.coli dan diberi madu. Penelitian ini merupakan penelitian eksperimental menggunakan 16 ekor tikus putih yang dibagi dalam satu kelompok kontrol negatif $(\mathrm{KN})$ dan tiga kelompok perlakuan (KP). Kelompok kontrol negatif diberi pelet biasa selama 14 hari; KP 1 diberi pelet dan madu 2 $\mathrm{mL} /$ hari selama 35 hari; KP 2 diberi pelet dan E. coli $1 \mathrm{~mL} /$ hari melalui selama 7 hari; serta KP3 diberi pelet, E. coli $1 \mathrm{~mL} /$ hari selama 7 hari, dan madu $2 \mathrm{~mL} /$ hari selama 35 hari. Organ limpa tikus diproses untuk dibuat sediaan jaringan histologi. Jaringan limpa tikus KN dan KP1 menunjukkan gambaran histologik yang sesuai dengan limpa normal. Jaringan limpa tikus KP2 menunjukkan kongesti akut dan vasodilatasi pembuluh darah, sedangkan pada KP3 tampak kongesti yang lebih ringan dari yang terlihat pada KP2 dan adanya tanda regenerasi sel-sel limfohematopoietik jaringan limpa. Dengan demikian dapat disimpulkan bahwa kelompok perlakuan yang diberi E.coli tanpa pemberian madu menunjukkan suatu splenitis akut non spesifik, sedangkan kelompok perlakuan yang diberi E.coli dengan pemberian madu menunjukkan tanda-tanda perbaikan dari radang dan tanda regenerasi sel.
\end{abstract}

Kata kunci: Madu, Eschericia coli, Limpa.

\begin{abstract}
Antimicrobial force in his sugar content of honey is influenced by the high level of acidity of honey, as well as flavonoid that can bind free radicals and fight the infection agent. Eschericia coli can cause local infection of the body's organs, reaching the blood stream, and give rise to sepsis. This study aimed to determine changes in histological picture of the spleen tissue of mice given infected E.coli and gave honey. An experimental study using 16 rats divided into one negative control group (KN) and tree treatment groups (KP). Negative control group given normal pellets for 14 days. KP1 is given pellets and honey $2 \mathrm{~mL} /$ day for 35 days. KP2 are given pellets and $E$. coli $1 \mathrm{~mL} /$ day through 7 days. KP3 given pellets, $E$. coli $1 \mathrm{~mL} /$ day for 7 days, and honey for 35 days. Mouse splenic processed and examined through a microscope. Mice of KN network and KP1 showed normal histological picture of the spleen. Spleen of KP 2 show today showed acute congestion and vasodilation of blood vessels spleen. Spleen of KP3 show a little more congestion and an indication of regeneration.It can be concluded that the treatment groups were given $E$. coli without giving honey showed a nonspecific acute splenitis, whereas the treatment group given E. coli with honey granting remission to show signs of inflammation.
\end{abstract}

Key words: Honey, Eschericia coli, Spleen. 
Madu merupakan salah satu obat tradisional yang digunakan oleh masyarakat dan dikenal sejak 10.000 tahun yang lalu serta mempunyai kemampuan sebagai antimikroba. ${ }^{1}$ Hippocrates menemukan madu sebagai obat penyembuh luka kirakira 2500 tahun yang lalu. ${ }^{2}$ Madu yang sebagian besar terdiri dari karbohidrat, digunakan sebagai obat untuk bermacammacam penyakit seperti penyakit pencernaan, tifus abdominalis, disentri, malaria, penyakit tenggorokan, dan sebagai obat untuk keracunan. ${ }^{2}$

Secara ilmiah telah terbukti bahwa bakteri tidak dapat hidup dan berkembang di dalam madu karena madu mengandung kalium. $^{2}$ Kalium merupakan unsur yang mencegah kelembaban, sedangkan kelembaban sendiri merupakan unsur terpenting untuk pertumbuhan bakteri (efek inhibisi madu). Madu juga memiliki zat antibiotik seperti interferon yang bersifat antivirus dan inhibin yang dapat menghambat pertumbuhan bakteri. ${ }^{1}$ Hasil penelitian sebelumnya menyebutkan bahwa madu mempunyai aktivitas antibakteri dengan spektrum yang luas. Efek inhibisi madu terhadap pertumbuhan Eschericia coli, Bacillus subtillis, Pseudomonas aeruginosa, Klebsiella pneumonia dan Proteus mirabilis secara in vitro diteliti oleh Griffin (2003). $^{2}$

Escherichia coli merupakan salah satu dari bakteri enterik dan anggota flora usus normal. Bakteri ini bersifat patogen apabila berada di luar usus atau di lokasi lain di mana flora normal jarang ditemukan. ${ }^{2}$ Tempat yang paling sering terkena infeksi E.coli yaitu saluran kemih, saluran empedu, dan tempat-tempat lain di rongga abdomen. Pada kondisi pertahanan tubuh inang tidak adekuat, bakteri ini dapat menimbulkan infeksi lokal yang secara klinik dapat mencapai aliran darah dan menimbulkan sepsis. ${ }^{2}$

Infeksi yang terjadi pada tubuh manusia akan mengaktivasi sistem imunitas tubuh, yaitu suatu kelompok organ yang memproduksi sel-sel khusus yang bekerja sama dalam melawan infeksi ataupun masuknya benda asing ke dalam tubuh (sebagai antigen). Limpa mengandung banyak makrofag dan merupakan tempat pembentukan limfosit aktif dan antibodi. Adanya kontak erat antara sel-sel ini dalam sirkulasi darah sangat berperan dalam pertahanan tubuh terhadap mikroorganisme, partikel asing, sel abnormal dan dalam mengeluarkan eritrosit tua atau abnormal. Jadi, limpa merupakan organ penting tempat sel imun berkonfrontasi dengan mikroba asing dan filter darah yang sangat efektif. ${ }^{3}$

Penelitian sebelumnya yang dilakukan oleh Hidayah dan Makiyah (2005) ${ }^{4}$ menunjukkan adanya perbedaan gambaran histologik jaringan limpa tikus dalam ukuran diameter pulpa putih sebagai jaringan limfoid antara kelompok tikus yang diberi madu dan tidak diberi madu. Perbedaan ini dapat disebabkan oleh adanya aktivasi madu sebagai agen antimikroba di saluran pencernaan tikus. Daya antimikrobial madu membuat bakteri patogen yang masuk akan kehilangan aktivitasnya sebelum memasuki pembuluh darah saluran cerna. Darah yang sampai ke limpa tidak mengandung banyak kuman patogen dan memicu respon imun yang berbeda. Penelitian ini dilakukan untuk mengetahui efek pemberian madu terhadap gambaran histologik jaringan limpa tikus yang telah diinfeksi E.coli.

\section{METODE PENELITIAN}

Penelitian ini merupakan penelitian eksperimental yang dilakukan sejak bulan Oktober 2012 sampai bulan Januari 2013. Penelitian dilakukan di Laboratorium Riset Biomedik dan Bagian Patologi Anatomi Fakultas Kedokteran Universitas Sam Ratulangi Manado. Subyek penelitian adalah 16 ekor tikus putih dewasa yang dibagi dalam empat kelompok, yaitu kelompok kontrol negatif, kelompok perlakuan madu (KP1), kelompok perlakuan E.coli (KP2), dan kelompok perlakuan madu dan E.coli (KP3).

Variabel bebas dalam penelitian ini adalah madu dan bakteri E. coli sedangkan variabel terikat adalah gambaran histologik jaringan limpa. Madu diperoleh dari desa Pangu kecamatan Tatengesan kabupaten 
Minahasa Tenggara dan kultur E. coli dari Laboratorium Mikrobiologi RSUP Prof. Kandou dan Laboratorium Kanaka Manado.

Kelompok kontrol negatif diberi diet standar pelet dan air selama 14 hari dan diterminasi pada hari ke-15. Tikus KP1 diberi diet standar pelet dan air, serta diberikan madu sebanyak $2 \mathrm{ml} /$ hari selama 35 hari dan diterminasi hari ke-36. Tikus KP2 diberi diet pelet dan air selama 7 hari serta diinfeksi bakteri E.coli $10^{6} \mathrm{cfu} / \mathrm{ml}$ sebanyak $1 \mathrm{ml} /$ hari kemudian diterminasi pada hari ke-8. Tikus KP3 diberi diet standar pelet dan air serta madu sebanyak 2 $\mathrm{ml} /$ hari selama 35 hari, tetapi pada hari ke15-22 diinfeksi bakteri E.coli diberikan $10^{6}$ cfu/ml sebanyak $1 \mathrm{ml} / \mathrm{hari}$ kemudian diterminasi pada hari ke-36. Bakteri diberikan melalui suntikan pada perut kanan bawah tikus (intraperitoneal) sedangkan madu diberikan melalui Naso Gatrial Tube (NGT). Jaringan limpa diproses dan dibuat sediaan histologi dengan pewarnaan Hematoksilin Eosin (HE). Sediaan diperiksa menggunakan mikroskop untuk melihat gambaran histologik jaringan limpa tikus.

\section{HASIL DAN PEMBAHASAN}

Jaringan limpa tikus wistar KN dan KP1 menunjukkan gambaran histologik yang sesuai dengan limpa normal, yaitu pulpa merah (pulpa rubra) yang terdiri dari sel makrofag, sel plasma, dan elemen darah; dan pulpa putih (pulpa alba) yang terdiri dari limfosit yang tersusun padat di dalamnya dan arteri sentralis pada bagian tengahnya (Gambar 1). Gambaran histologik yang berbeda terlihat pada jaringan limpa tikus putih KP2, yaitu pulpa putih terdiri dari limfosit yang tersusun tidak rapat karena merenggang (Gambar 2A) dan pembuluh darah yang melebar sebagai tanda adanya kongesti limpa (Gambar 2B). Gambaran mikroskopik jaringan limpa KP2 ini menunjukkan suatu splenitis akut non spesifik.

Splenitis akut nonspesifik dapat terjadi pada setiap infeksi yang penularannya melalui darah. Secara makroskopik limpa membesar, berwarna merah dan teraba sangat lunak. Secara mikroskopik terdapat kongesti pulpa merah akut dengan penipisan folikel limfoid dan hiperplasia retikuloendotelial. ${ }^{5}$ Peradangan limpa pada penelitian ini dapat terjadi karena E.coli yang diberikan secara intraperitoneal dapat menyebar dan masuk ke aliran darah dan sampai ke limpa sehingga menimbulkan reaksi non spesifik jaringan limpa terhadap infeksi. $^{4,5}$

Kongesti jaringan limpa dapat terjadi karena E.coli memicu pelepasan sitokin. ${ }^{5}$ Sitokin merupakan peptida pengatur (regulator) yang dapat diproduksi oleh hampir semua jenis sel berinti dalam tubuh.

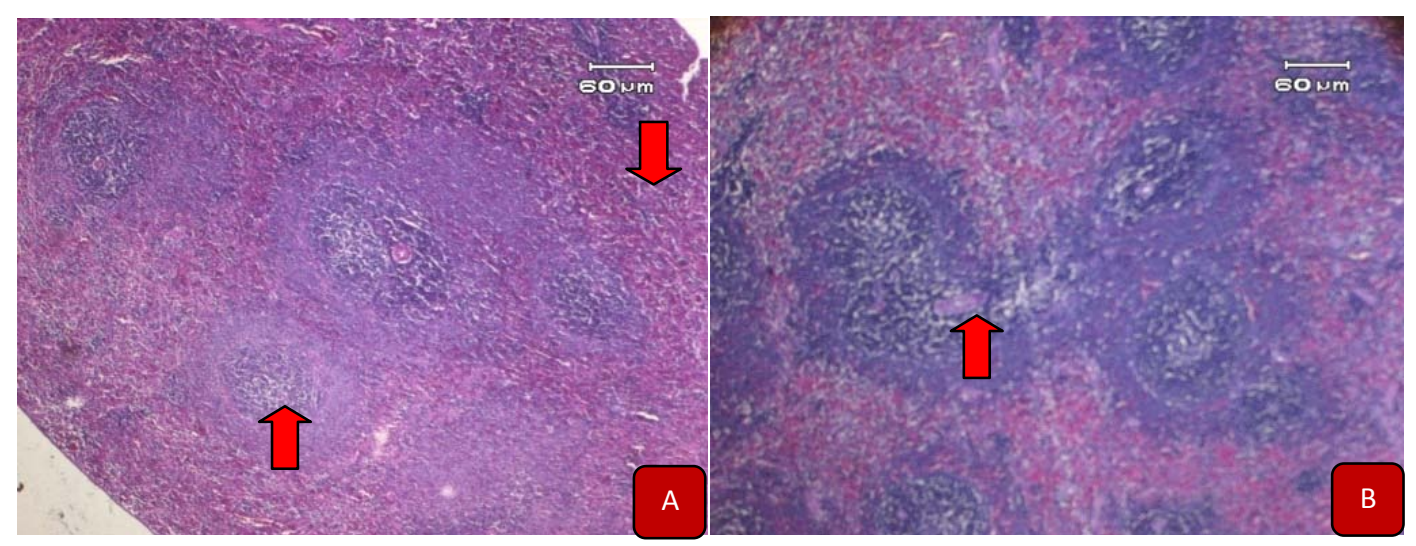

Gambar 1. Gambaran mikroskopik jaringan limpa kelompok kontrol negatif, KN (A) dan kelompok perlakuan 1, KP1 (B). Tampak jaringan limpa normal dengan pulpa putih dengan arteri sentralis di tengahnya dan pulpa merah. 


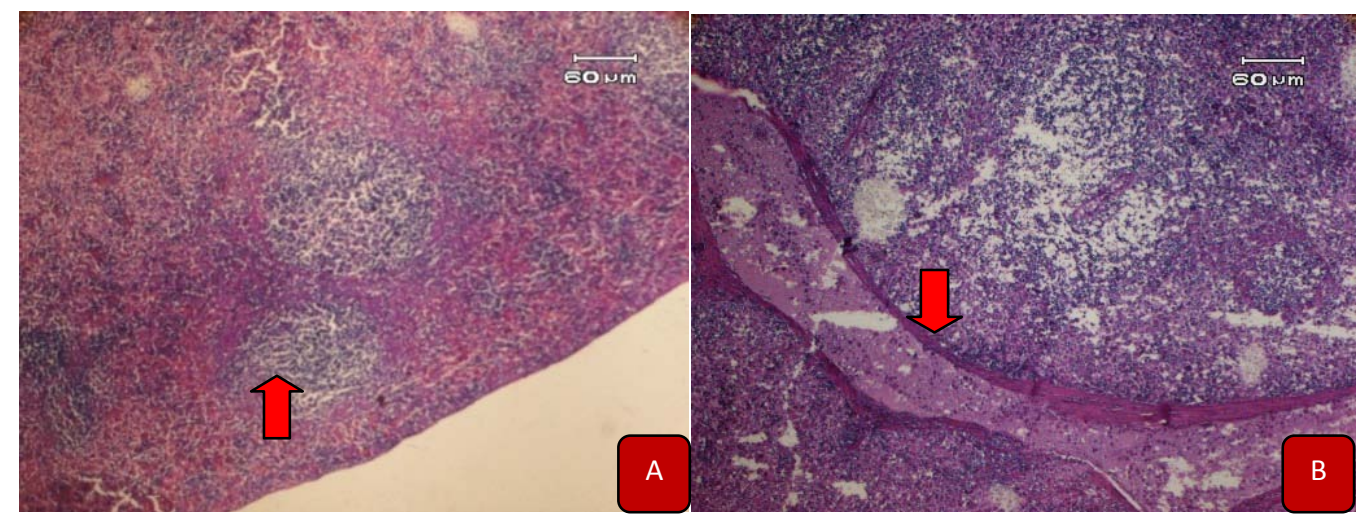

Gambar 2. Gambaran mikroskopik jaringan limpa kelompok perlakuan 2 (KP2). Tampak tanda-tanda kongesti limpa. A: Pulpa putih yang merenggang. B: Pembuluh darah yang melebar.

Umumnya sitokin mempunyai sel-sel sasaran yang tidak terlalu jauh letaknya sehingga sitokin tidak bergantung pada peredaran darah. Beberapa jenis sitokin, misalnya IL-3 dan GranulocyteMacrophage Colony Stimulating Factor (GM-CSF) yang dilepaskan oleh sel TCD $4^{+}$, membantu merekrut sel-sel efektor di daerah infeksi dengan cara menginduksi sel-sel induk dalam sumsum tulang untuk meningkatkan mielopoiesis. Dengan demikian terjadi penambahan sel-sel granulosit dan makrofag di daerah infeksi. ${ }^{6}$

Hasil yang menarik terlihat pada KP3 (diberikan madu $2 \mathrm{~mL} /$ hari selama 35 hari dan E.coli $1 \mathrm{~mL} /$ hari selama 7 hari). Jaringan limpa tikus pada kelompok ini menunjukkan tanda perbaikan dari kongesti akut berupa sedikit vasodilatasi, pulpa merah dan pulpa putih tidak merenggang, serta banyak sel-sel makrofag, fokus-fokus fibrosis, dan sel-sel besar Hematopetic stem cells (HSc) seperti yang terlihat pada gambar 3. Pelepasan HSc dipicu oleh GMC-SF. Madu dengan kandungan antimikrobanya memiliki peran penting dalam proses perbaikan jaringan limpa dan peradangan ini. Madu mengandung substansi yang bersifat antimikroba yaitu hidrogen peroksida, flavonoid, dan phenolic acid ( caffeic acid dan ferulic acid). ${ }^{7}$ Flavonoid merupakan senyawa hasil fotosintesis sel yang terkandung dalam madu yang banyak digunakan pada penelitian bahan anti-infeksi.

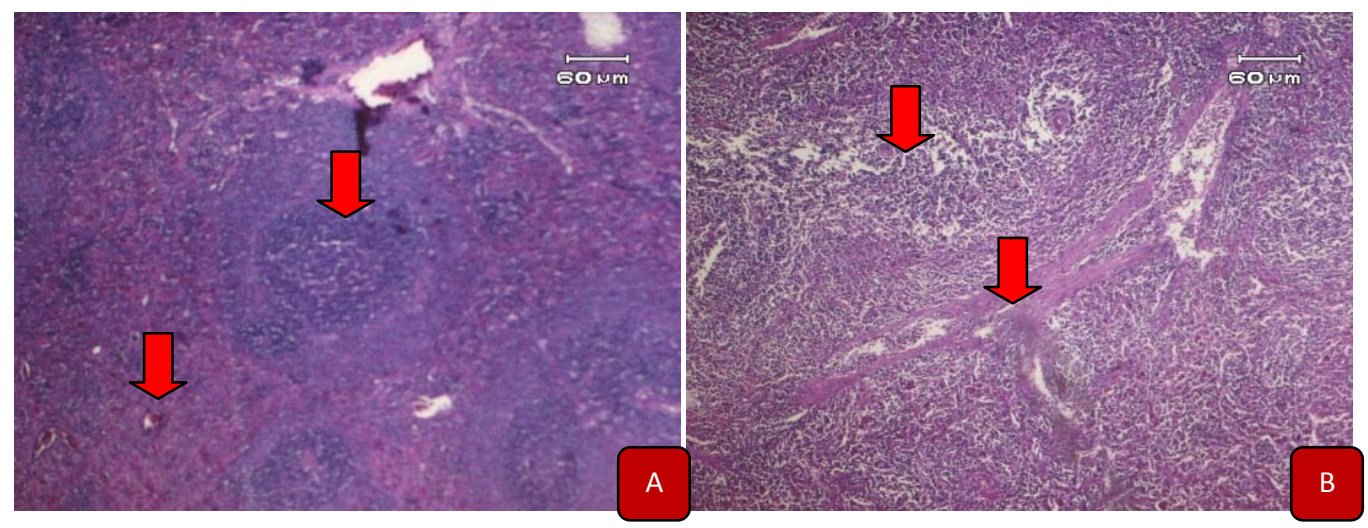

Gambar 2. Gambaran mikroskopik jaringan limpa kelompok perlakuan 3 (KP3) menunjukkan perbaikan dari kongesti akut limpa. A: Pulpa putih dan pulpa merah yang tidak merenggang. B: Sedikit vasodilatasi, sel makrofag, fokus-fokus fibrosis, dan HSc. 

Flavonoid diisolasi, diidentifikasi, dan dikelompokkan menurut kelompoknya, diantaranya flavon, isoflavon, flavonol, flavan, flavanon, kalkanon. Penelitian lebih jauh membuk-tikan flavon (apigenin, vitexin, saponarin, chrysin dan luteolin) serta flavonol (quercetin) mampu menghambat infeksi bakteri dengan mekanisme yang berbeda. Apigenin, vitexin, dan saponarin yang memiliki tiga kelompok hidroksil pada cincin A dan B aktif melawan basil gram positif dan gram negatif, termasuk E.coli. ${ }^{8}$ Selain itu, luteolin secara lengkap menginhibisi xanthine oksidasi yang berfungsi mengaktifkan pembentukan superoksida pada sistem radikal bebas. Luteolin dan chrysin menurunkan pembentukan radikal hikdroksil. Luteolin menekan pembentukan $\mathrm{PGE}_{2}$, menghambat ekspresi dari siklooksigenase, dan memasangkan $\mathrm{O}_{2}^{-}$pada sistem radikal bebas. ${ }^{9}$

\section{SIMPULAN}

Tikus yang diberi E.coli tapi tidak diberi madu menunjukkan suatu splenitis akut non spesifik, sedangkan tikus yang diberi E.coli dan madu menunjukkan tandatanda perbaikan dari peradangan limpa dan regenerasi sel.

\section{SARAN}

Perlu dilakukan penelitian dengan dosis madu yang beragam agar diketahui dosis minimal untuk pemberian madu pada tikus yang diinfeksi E. coli dan perlu penambahan jumlah hewan uji agar hasil yang diperoleh akan lebih akurat.

\section{DAFTAR PUSTAKA}

1. Rio YBP, Djamal A, Asterina. Perbandingan efek antibakteri madu asli sikabu dengan madu lubuk minturun terhadap Escherichia coli dan Staphylococcus aureus. Jurnal Kesehatan Andalas. 2012;1(2).

2. Suganda, Jaka. [Skripsi] Uji efektifitas madu sebagai antimikroba terhadap Salmonella typhi secara in vitro. Fakultas Kedokteran Universitas Brawijaya. 2005

3. Wangko S. Catatan kuliah kajian histofisiologik sistem limfatik. BIK Biomed. 2008; 4(1).

4. Hidayah FN, SNN, Makiyah. Gambaran histologis limpa (lien) setelah paparan madu pada tikus putih (Rattus norvegicus). Jurnal Kedokteran Yarsi. 2005;13 (1) : 616.

5. Robbins, Cotran. Buku saku dasar patologis penyakit. Jakarta: EGC. 2006; p. 425

6. Subowo. Immunobiologi, Edisi 2.Jakarta: SS. 2009; P. 121.

7. Cushnie TPT, Lamb AJ. Antimicrobial activity of flavonoids. International journal of antimicrobial agents. 2005. 26: 343-356.

8. Bylka W, Matlawska I, Pilewski NA. Natural flavonoids as antimicrobial agents. JANA. 2004. 7(2).

9. Harris KG dkk. Luteolin chrysin differentially inhibit cyclooxygenase-2 expression and schavenge reactive oxygen species but similarly inhibit prostaglandin$\mathrm{E}_{2}$ formation in RAW 264.7 cells. 2006. JN 0022-3166. 